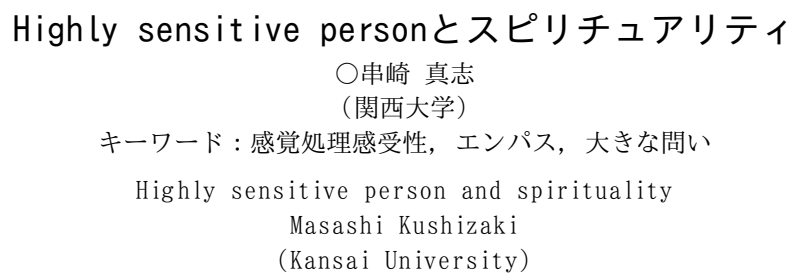

Key Words : sensory processing sensitivity, empath, big question

目的

Highly sensitive person（高敏感者）は，聴覚・視覚・触 覚・嗅覚などに, 特異な感覚処理感受性 (sensory processing sensitivity) をもつ人を指す（Aron et al.， 2012)。Aron (2010, p. 24) は, 高敏感者の特徵の一つとし て，物事を深く考える（depth of processing）傾向をあげて いて，彼らは世界の行く未や人生・仕事の意味を熟考すると 述べている。高敏感者が神秘体験（mystical experiences） をもちやすいことは報告されているが (Kjellgren, Lindahl， \& Norlander, 2009), スピリチュアルな態度や人生観との関 連については研究が見当たらない。本研究ではそれを質問紙 によって検討する。

\section{方 法}

参加者 専門科目・教養科目の心理学を受講する大学生 126 名（男性48名, 女性77名, その他 1 名, $M=19.3$ 歳, $S D=$ $0.95)$ が参加した（実施時期2019年1月）。

質問紙 [1]Highly sensitive person尺度短縮版（Aron et al.,2010）11項目7件法。訳文は高橋（2016）を使用し た。[2]エンパス尺度9項目版 (Nine-item Empath Scale: 串 崎，2019）9項目7件法。他者に対する敏感さを測定する尺度 で，0rloff（2017）の記述を元に筆者が作成。[3]刺激追求 尺度（brief sensation seeking scale：柴田・古澤, 2013） 8項目5件法。Aron (2010，p. 14) は，高敏感に刺激追求の性 質を持ち合わせた high sensation seekers が一定数いると 述べている。[4]Big question尺度（村上, 2013）から「人生 の意味の希求」因子。「人生で本当に大切なこと, すべきこ と，したいことは何か」「本当の幸せとは何なのか」「生き ることや人生に意味や目的はあるのか」等 6 項目について，ふ だんどれくらい考えるかを6件法（1=全く考えない，6=よく考 える）で回答した。[5]自己超越傾向尺度（self-

transcendence scale：中村，1998）功超越性因子。「人 のいのちは，姿形を変えて永遠に存在すると思う」「人が死 んでも, 自然の一部になって生き続けることができると思 う」等4項目について，5件法（1=あてはまらない，5=あては まる）で回答した。原文では「自分のいのち・・」となって いるが，「人のいのち・・」のように人生観を問う質問に変 更した。

手続き 授業終了後に協力を依頼し，任意の参加に同意を 得たうえで, Google form上で自発的に回答した。

\section{結 果}

確認的因子分析 エンパス尺度について3因子モデルの確認 的因子分析を行い, 串崎 (2019) と同様に, 気疲れ

(emotional hangovers) 「雑踏や人混みは, 気疲れするので 好きではない」等4項目, 情動吸収 (emotional sponges)

「相手の気持ちやストレスを，知らないあいだに取り込んで
いる」等3項目，情動直感 (emotional intuition)「相手を見 るだけで, 相手の気持ちがぱっとわかる」等2項目を得た。

相関係数 内的整合性 $\alpha$ 係数を確認したのち，各尺度間の 相関係数を男女別に算出した（Table 1, Table 2)。女性で はHighly sensitiveがBig questionと自己超越に関連してい た。男性では情動直感がBig questionと自己超越に関連して いた。

$$
\text { 考 察 }
$$

女性は, Aron（2010）の指摘通り，高敏感であるほど人生 の意味（big question）やいのちの永遠性（自己超越）を考 えていた。他者に対する敏感さ（エンパス）では，情動直感 が男女共に関連していた。また, 男性においては刺激追求も 鍵となっていた。高敏感者には苦悩も多いが, その感覚世界 を深く探求していくことで, 豊かな人生を歩むことができる と思われる。

\section{引用文献}

Aron, E. N. (2010). Psychotherapy and the highly sensitive person. New York: Routledge.

Aron, E. N., Aron, A., \& Jagiellowicz, J. (2012). Personality and Social Psychology Review, 16, 262-282. Kjel lgren, A., Lindahl, A., \& Norlander, T. (2009). Imag ination, Cognition and Personal ity, 29, 135-146.

\begin{tabular}{lcccccc}
\multicolumn{7}{c}{ Table 1 各尺度の相関係数 (男性 $n=48)$} \\
\hline & 2 & 3 & 4 & 5 & 6 & 7 \\
\hline 1. 気疲れ & -.050 & -.164 & .091 & .025 & .118 & -.055 \\
2. 情動吸収 & & $.293 *$ & .092 & -.042 & .276 & $.319 *$ \\
3. 情動直感 & & & .153 & $.343 *$ & $.365 *$ & $.328 *$ \\
4. Highly sensitive & & & & $.306 *$ & .040 & -.132 \\
5. Sensation seeking & & & & $.455 * *$ & .123 \\
6. Big question & & & & & .153 \\
7. 自己超越傾向 & & & & & & \\
\hline
\end{tabular}

\begin{tabular}{lccccccc}
\hline \multicolumn{7}{c}{ Table 2 各尺度の相関係数 (女性 $n=77)$} \\
\hline & 2 & 3 & 4 & 5 & 6 & 7 \\
\hline 1. 気疲れ & -.018 & -.158 & -.068 & -.083 & -.190 & $-.289 *$ \\
2. 情動吸収 & & $.281 *$ & $.369 * * *$ & .046 & .160 & .022 \\
3. 情動直感 & & & $.232 *$ & .001 & $.250 *$ & .075 \\
4. Highly sensitive & & & & -.026 & $.446 * *$ & $.230 *$ \\
5. Sensation seeking & & & & & .075 & .204 \\
6. Big question & & & & & & $.309 * *$ \\
7. 自己超越傾向 & & & & & & & \\
\hline
\end{tabular}

